\title{
CISD2 wt Allele
}

National Cancer Institute

\section{Source}

National Cancer Institute. CISD2 wt Allele. NCI Thesaurus. Code C116300.

Human CISD2 wild-type allele is located in the vicinity of $4 q 24$ and is approximately $24 \mathrm{~kb}$ in length. This allele, which encodes CDGSH iron-sulfur domain-containing protein 2 , is involved in both iron-sulfur binding and autophagy. Mutation of the gene is associated with Wolfram syndrome 2 . 